ISA

Arboriculture \& Urban Forestry 2016. 42(3): 201-212

\title{
Inspection and Evaluation of Decay Damage in Japanese Cedar Trees Through Nondestructive Techniques
}

\author{
Cheng-Jung Lin, Chia-Ju Lee, and Ming-Jer Tsai
}

\begin{abstract}
The purpose of this study was to investigate the standard values of living, undamaged Japanese cedar (Cryptomeria japonica) trees through different nondestructive techniques. This study also detects the stress wave velocity (V) and tomogram (VT), and resolves corresponding V maps of Japanese cedar trees with and without decay damage for tree risk assessment. A visual tree inspection form, with seven categories of tree damage, is proposed for tree hazard assessment. Different nondestructive evaluation parameters can serve as an index for diagnosing standard values (with or without decay). The VT and corresponding stress wave velocity maps of decay-damaged and damaged Japanese cedar trees can detect the general location and area of wood deterioration. The transversal acoustic velocity values increased with increasing diameter in undamaged trees, and the difference between the maximum and minimum $\mathrm{V}$ value of the trunks in undamaged trees fell within a range of constants. The proposed approach can be combined with other non-destructive techniques to better examine and confirm the situation of trees.

Key Words. Cryptomeria japonica; Japanese Cedar; Nantou; Nondestructive Technique; Stress Wave; Taiwan; Tomography; Tree Hazard Assessment; Visual Tree Inspection.
\end{abstract}

The Japanese cedar (Cryptomeria japonica) tree is a common landscape tree in Xitou Nature Education Area, Nantou, Taiwan. This type of tree is often planted along both sides of the trail in this forest recreation area. The trees growing on the roadside suffer from manmade and squirrelbite damage (Figure 1), and often fall without warning. This could lead to human casualties or result in property loss. Trees suffering from manmade and squirrel-bite damage topple easily due to failure occurring at the base of the trunk.

Concerns about public safety and urban tree conservation strongly support the development and application of rapid, precise, and cost-efficient diagnostic techniques to detect decay and other types of structural defects in trees (Wang and Allison 2008). Standing trees must be evaluated in order to maintain in situ structural safety for tree risk assessment. Various nondestructive techniques (NDTs) have been applied to detect decay and deterioration in trees in order to identify hazardous trees. NDTs regard the science of identify- ing the physical and mechanical properties of a piece of material without altering its end-use capabilities then use this information to make decisions regarding appropriate applications (Pellerin and Ross 2002). Visual tree assessment, a systematic method of tree assessment using biological and biomechanical indicators to evaluate overall vitality and structural integrity of a tree, includes visual inspection of the tree to look for external evidence of internal defects, instrumental measurements of internal defects, and evaluation of the residual strength of the wood (Mattheck and Breloer 1994). Arboriculturists consider visual tree assessment (i.e., structural defects) an essential practice. This kind of assessment serves as the starting point for evaluating tree defects and providing basic information about tree growth performance and stability. Gruber (2008) indicated that tree breakage depends on many features of the tree, including its height, width of crown, crown architecture, crown density in the branching and leaves, form, condition, physical wood properties, and species. 


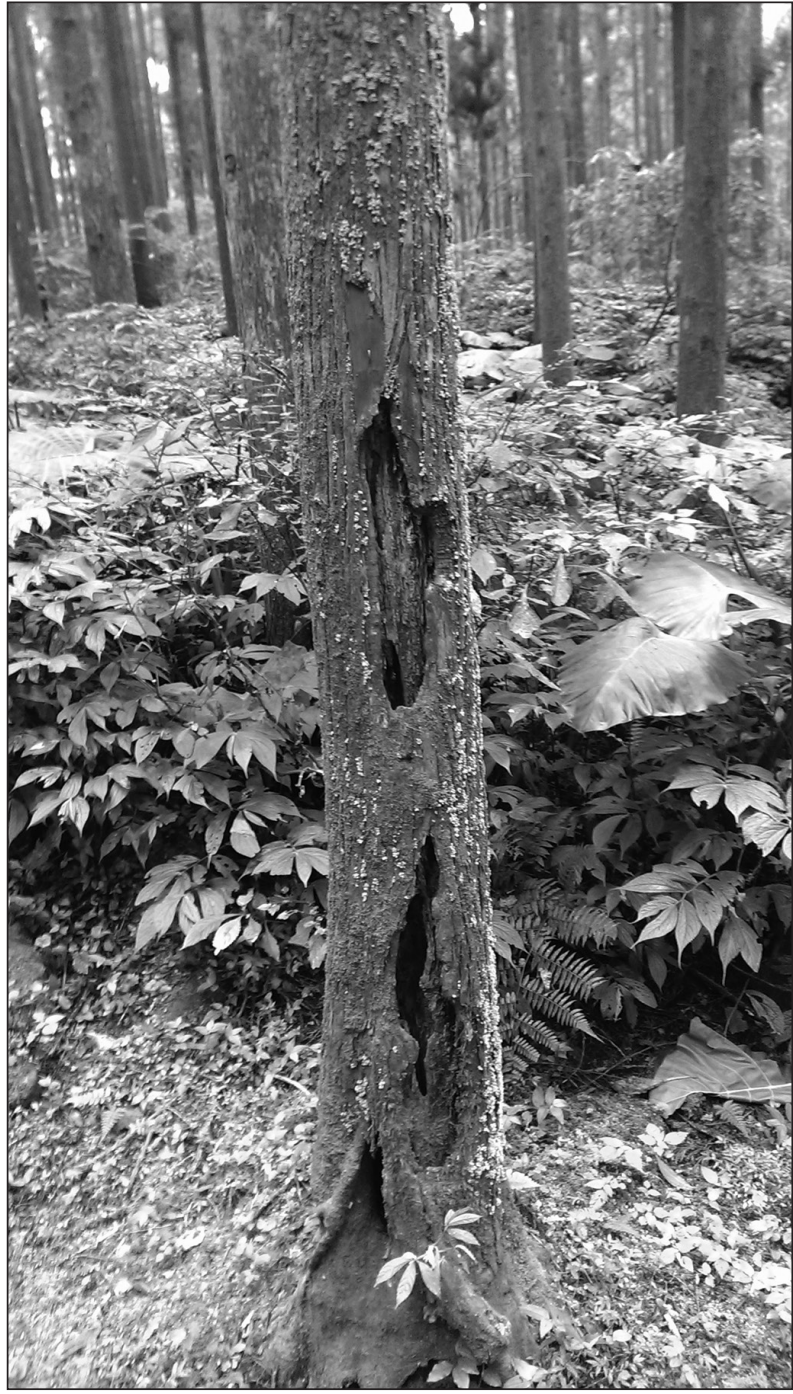

Figure 1. Decay damage of Japanese cedar (Cryptomeria japonica) trees in Xitou Nature Education Area.

Stress and ultrasonic wave evaluation measurements of wood have proven to be effective parameters for detecting and estimating deterioration in tree trunk and wood structures (Lin et al. 2000; Pellerin and Ross 2002). NDTs have been developed for tomographic investigation (Rinn 1999). Acoustic tomographic measurements in wood have been found to be effective in detecting and estimating decay in tree trunks (Gilbert and Smiley 2004; Bucur 2005; Wang et al. 2007; Deflorio et al. 2008; Lin et al. 2008; Wang and Allison 2008; Wang et al. 2009; Lin et al. 2011a; Lin et al. 2011b; Lin et al. 2013). Acoustic tomography has been proven to be the most effective technique for detecting internal decay, locating the position of defects, and estimating their size, shape, and characteristics. In addition, because the location of decay is more important in terms of strength loss than just the size of the area of decay, acoustic tomography allows researchers to determine relative strength loss (Rinn 2011).

A drilling technique can be applied to determine the position and nature of a defect (Wang et al. 2005; Wang et al. 2007; Wang and Allison 2008; Li et al. 2011). A fractometer is a device that breaks the radial increment core along the direction of the fiber to measure the fracture strength (Lin et al. 2007). Many diagnostic tools, such as the RESISTOGRAPH $^{\oplus}$ or other resistance-drilling devices, acoustic detectors, electrical conductivity meters, and fractometers are available for detecting internal decay and other defects in living trees (Larsson et al. 2004). These NDTs can be used in combination to achieve better accuracy in determining the location and extent of wood deterioration.

In previous studies, wood decay of squirreldamaged standing trees in Luanta China fir was detected by an ultrasound method (Lin et al. 2000), and defects in living Japanese cedar trees were inspected by ultrasonic tomography (Lin et al. 2008). No detailed reports have been published about detecting wood decay damage in Japanese cedar trees by different nondestructive techniques. Therefore, the first objective of this study was to detect the evaluation parameters of living, undamaged (without decay) Japanese cedar trees by stress wave, drilling resistance, lateral impact vibration, fractometer, and density profile techniques. Researchers also generated tables of standard values (references) to aid in the use of these methods in wood deterioration surveys. A secondary objective was carried out to investigate transversal stress wave velocity tomogram (VT), and resolve corresponding stress wave velocity (V) maps of Japanese cedar trees with decay damage to understand the degree and extent of trunk deterioration for tree risk assessment.

\section{MATERIALS AND METHODS}

First, the experiment was carried out in situ on 89 sound Japanese cedar trees (Groups A and B planted in the Tower Area, Groups C and D planted in the Castle Area, and Groups E and F planted in the Ridge Area) in Xitou Nature Education Area, Nantou, Taiwan. These trees were inspected in 2014, when the trees were about 36-60 years old with average diameters at breast height (DBHs) of 
21.9-38.1 cm. Multiple stress wave measurements (Fakopp Enterprise, Agfalva, Hungary) were carried out at eight equidistant points (eight probes) along the circumference on the trunks. All sensors were located in the trees at about $130 \mathrm{~cm}$ above ground and the transducer was connected at an angle of 90 degrees to the trunk axis to detect the propagated travel time and stress waves. The transmitter probe was first positioned at point 1 with stress wave pulses acquired by the receiver probe at the other seven points. Hammer tapping was done from points 1 through 8, respectively. Measurements were repeated with the transmitter probe positioned at each point, thus giving 28 independent propagation time measurements for each investigated section [for a complete round trip: 7 receiving probes $\times 8$ transmitter probes $\div 2$ (the same path was measured twice)] A complete data matrix was obtained through this measurement process at each test location.

The circumference of each cross section and the distances between sensors were measured using a tape measure. These measurements served as inputs for the system software to map the approximate geometric form of the cross sections. Firstly, upon completing acoustic measurements, a tomogram was constructed for each cross section using the ArborSonic software. Secondly, due to differences in species and paths, a two-dimensional (2D) image was obtained using this software based on original stress wave transmission times (no adjusted and regularized times) to better understand the experimental values in this study. To quantitatively assess the tomograms, all corresponding stress wave velocities were further calculated at each pixel of the tomogram by visualizing and converting the tomograms to yield stress wave velocity maps of the cross sections (e.g., Figure 2; Figure 3; Figure 4).

After the stress wave characteristic information of each cross section provided by the tomograms was tabulated, the resonant frequencies were measured using a portable lateral impact vibration meter (Ponta, World Enterprise, Japan) to diagnose the wood quality inside a standing tree. The product $\mathrm{D} \cdot \mathrm{F}(\mathrm{m} \bullet \mathrm{Hz})$ of the resonance frequency $\mathrm{F}$ of the vibration or the sound of an impacted tree trunk and the trunk diameter $\mathrm{D}$ serve as the diagnosis index.

Then, drilling resistance measurement was conducted using the an F400 (IML, Gmbh, Germany). The drilling paths ran in the radial direction from the bark to the pith of a trunk cross section. Sound wood is dense, hard in texture, and has high resistance to drill penetration. In contrast, severely decayed wood is less dense, softer in texture and has low drilling resistance (Pokorny 1992). Finally, $5 \mathrm{~mm}$ diameter cores were cut from the trunk using an increment borer. A fractometer was used

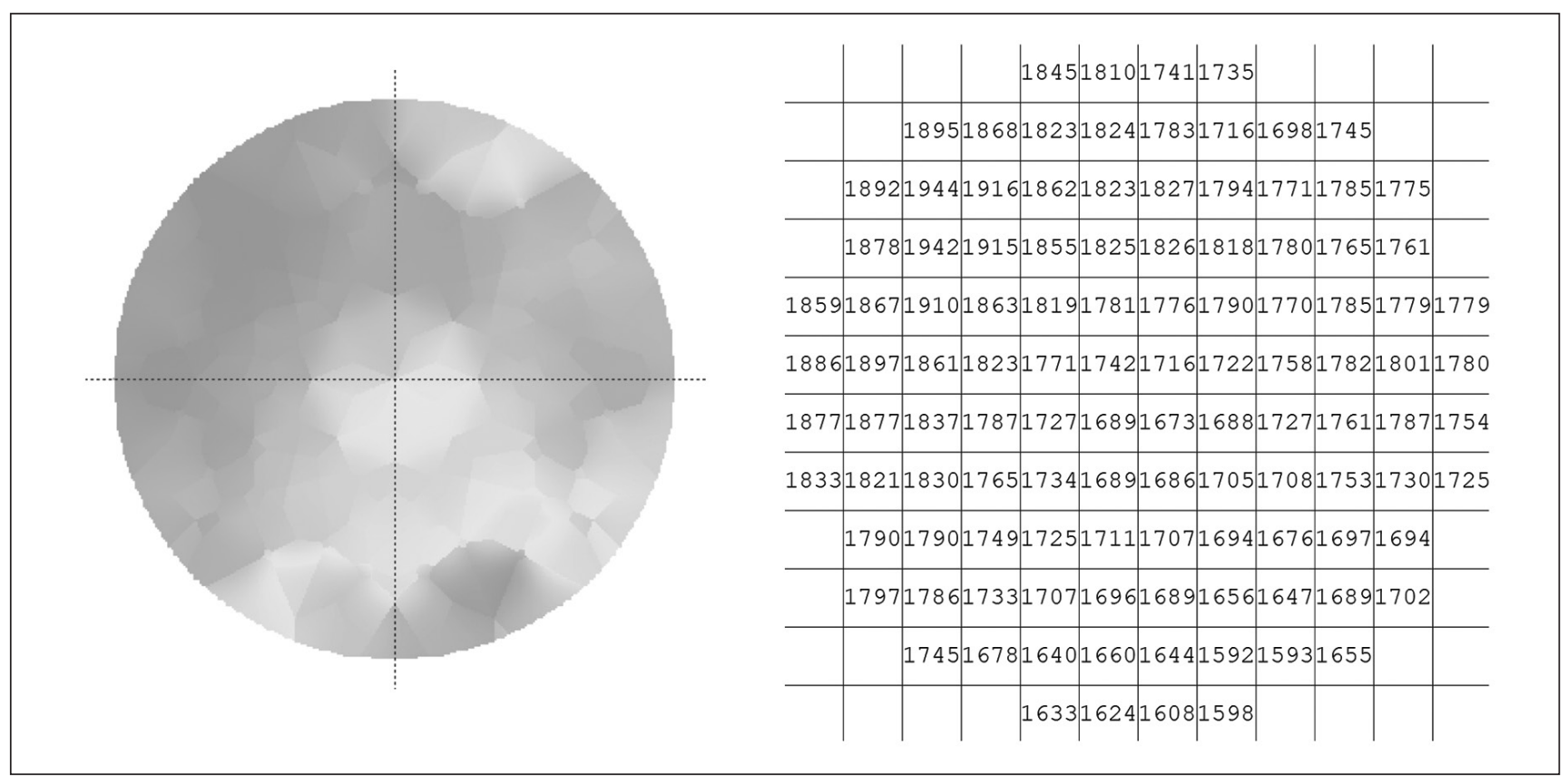

Figure 2. Stress wave velocity tomogram and the corresponding stress wave velocity map grids $(3 \mathrm{~cm} \times 3 \mathrm{~cm})$ of an undamaged tree (Group A, no. 1, velocity range, 1,415-1,961 m/sec). 

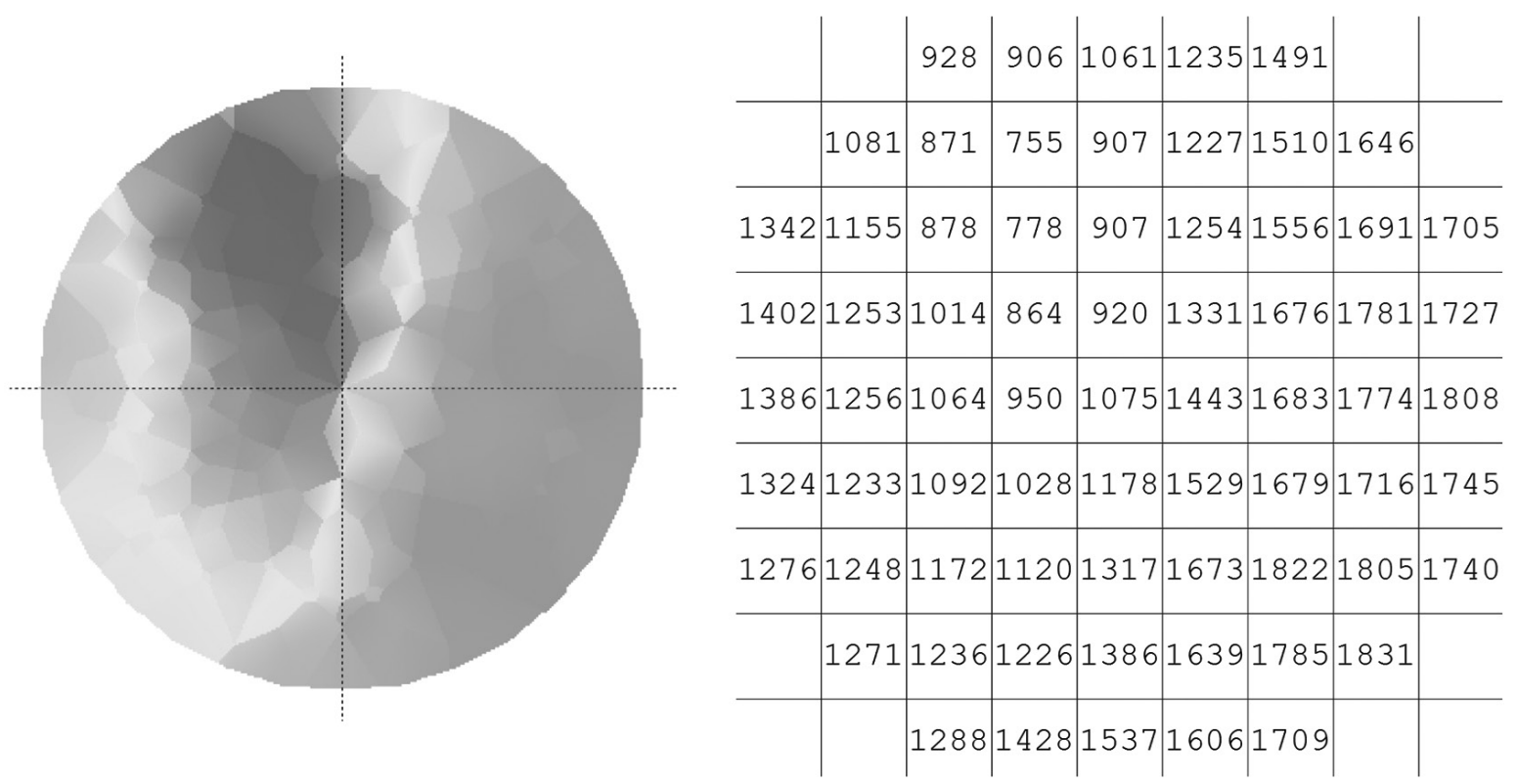

Figure 3. Stress wave velocity tomogram and the corresponding stress wave velocity map grids $(3 \mathrm{~cm} \times 3 \mathrm{~cm})$ of a damaged tree (Group G, no. 22, velocity range, $674-1,879 \mathrm{~m} / \mathrm{sec}$ ).

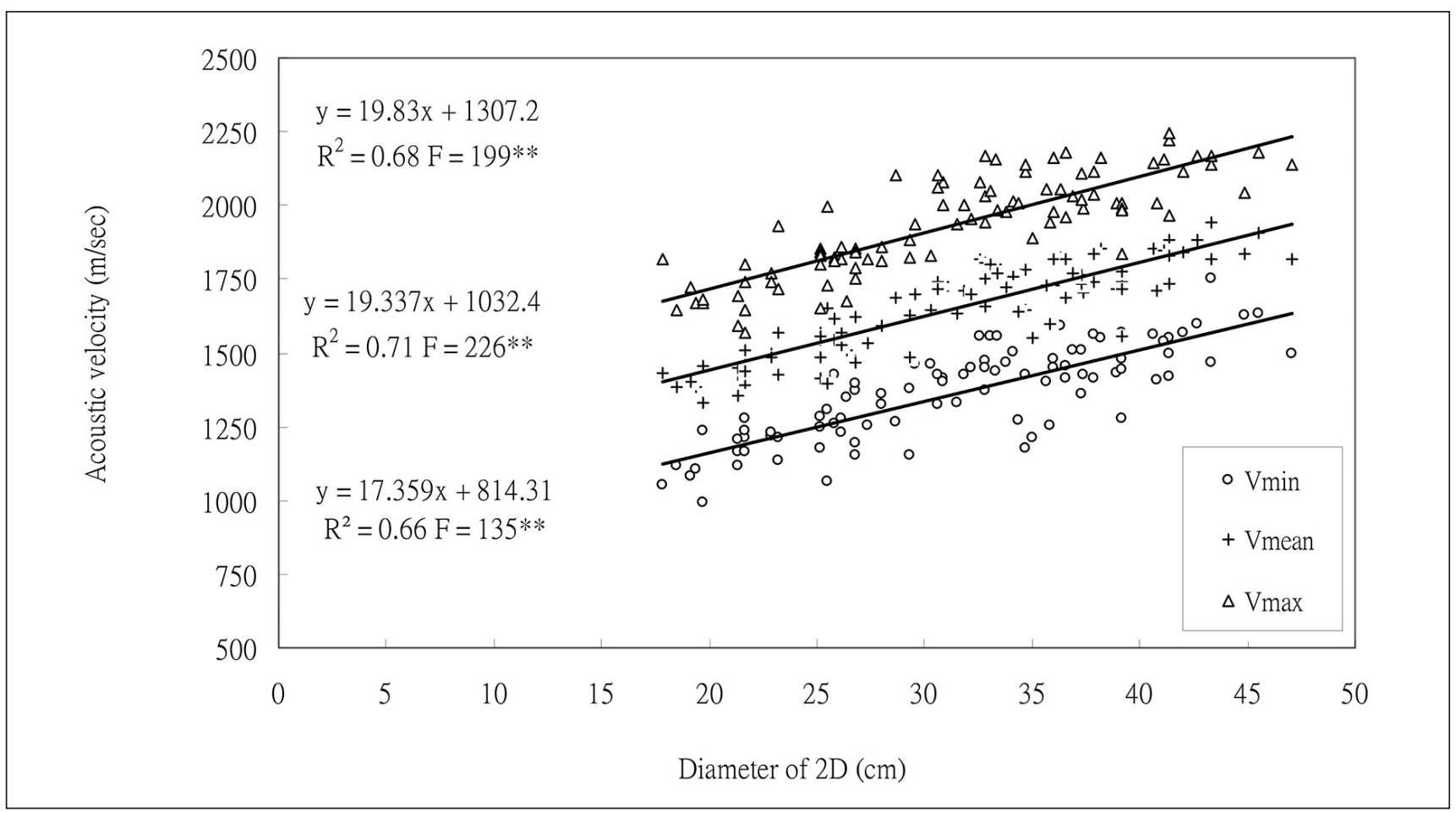

Figure 4. Relationships between trunk diameter and transversal acoustic velocities of tomogram in undamaged trees.

to evaluate the crushing strength of core samples (in green state) in the bark to the pith direction at an interval of $6 \mathrm{~mm}$. Finally, a core specimen was mounted and processed into slices (wideness $\times$ thickness $=17 \mathrm{~mm} \times 2.0 \mathrm{~mm}$ ) for X-ray densito- metric scanning. The conditioned slices (air dried) were subjected to a direct-reading X-ray densitometer (QTRS-01X Tree Ring Analyzer, Quintek Measurement Systems, Knoxville, Tennessee, U.S.) to determine the tree ring (wood) density profile. Table 
1 summarizes the nondestructive evaluation methods used for tree assessment in this experiment.

The experiment was also carried out in situ on 24 different decay-damaged Japanese cedar trees (Group G, planted along both sides of the trail) in the Tower Area of the Xitou Nature Education Area. These trees were investigated in 2014, when the trees were about 60-yearsold with diameters at breast height of 28.3-83.1 $\mathrm{cm}$. Tree trunk deterioration was detected by stress wave tomography (using the same method previously described). After the stress wave velocity tomography information (2D image) of each cross section provided by the tomogram was tabulated, the sampling core method was conducted using an increment corer to understand the wood deterioration (with or without decay damage) by the visual method.

\section{RESULTS}

Seven categories of tree defects and appearance were inspected by the visual tree inspection form (see APPENDIX). The seven main defects were decayed wood, cracks, root problems, weak branch unions, cankers, poor tree architecture (trunk and branch), and dead trees, tops, or branches. First, the Japanese cedar trees were inspected visually, focusing on different decay-damaged trees.

The evaluated parameters of different nondestructive techniques, including the average lateral impact vibration performance, drilling resistance value, green crushing strength, and air-dried wood density were $284.6 \mathrm{~m} \mathrm{~Hz}, 18.5 \%, 186.2 \mathrm{kgf} /$ $\mathrm{cm}^{2}$, and $500.4 \mathrm{~kg} / \mathrm{m}^{3}$, respectively (Table 2 ). The transversal stress wave velocity, lateral impact vibration performance, drilling resistance value, green crushing strength, and air-dried wood density of a normal undamaged tree stem serve as the index of diagnosis or standard reference value.

The average minimum and maximum $\mathrm{V}$ values were $1,159-1,488 \mathrm{~m} / \mathrm{sec}$ and 1,721-2,080 m/sec, respectively, for the 89 undamaged Japanese cedar trees planted in four different areas (Table 3). The mean $\mathrm{V}$ value of the tomogram was $1,440-1,772$ $\mathrm{m} / \mathrm{sec}$. In the undamaged trees group, the average $\mathrm{V}$ valves (minimum, maximum, and mean) of the larger diameter class were higher than those of the smaller diameter class (Table 3). This result shows that different diameter classes affected the transversal acoustic velocity of the tomogram.

The average minimum and maximum $\mathrm{V}$ values were $1,159 \mathrm{~m} / \mathrm{sec}$ and $2,062 \mathrm{~m} / \mathrm{sec}$, for the 24 decay-damaged Japanese cedar trees, respectively (Table 4). The mean $\mathrm{V}$ of the tomogram was $1,610 \mathrm{~m} / \mathrm{sec}$. The average minimum $\mathrm{V}$ value of the trunks in the decay-damaged trees (Table 4) was clearly lower than that of the undamaged trees (Table 3$)$. The minimum $\mathrm{V}$ values $(1,354 \mathrm{~m} /$ sec) can be considered as the threshold values of diagnosis by stress wave velocity tomogram.

Table 1. Assessment of standard values (reference) in sound trees by different nondestructive techniques for tree hazard assessment.

\begin{tabular}{lll}
\hline Item & Methods & Evaluated parameter \\
\hline 1 & Visual tree inspection & Tree inspection form \\
2 & Acoustic device 2D tomogram & Transversal acoustic velocity $(\mathrm{m} / \mathrm{sec})$ \\
3 & Lateral impact vibration & Diameter $\times$ frequency $(\mathrm{m} \cdot \mathrm{Hz})$ \\
4 & Drilling resistance method & Drilling resistance value $(\%)$ \\
5 & Increment borer & Visual observation of core \\
6 & Fractometer & Crushing strength $\left(\mathrm{green}, \mathrm{kgf} / \mathrm{cm}^{2}\right)$ \\
7 & X-ray wood density profile & Density $\left(\right.$ air $\left.\mathrm{dried}, \mathrm{g} / \mathrm{cm}^{3}\right)$ \\
\hline
\end{tabular}

Table 2. Average measurements of sound trees by different nondestructive techniques.

\begin{tabular}{lllll}
\hline No. & $\mathrm{DF}(\mathrm{m} \mathrm{Hz})$ & $\mathrm{R}(\%)$ & $\mathrm{C}\left(\mathrm{kgf} / \mathrm{cm}^{2}\right)$ & $\mathrm{D}\left(\mathrm{kg} / \mathrm{m}^{3}\right)$ \\
\hline $\begin{array}{l}\text { Japanese cedar } \\
\text { (in this study) }\end{array}$ & 284.6 & 18.5 & 186.2 & 500.4 \\
& $(28.7)$ & $(7.0)$ & $(28.4)$ & $(93.0)$ \\
$\begin{array}{l}\text { Norfolk island pine } \\
\text { (Lin et al. 2015) }\end{array}$ & 381.3 & 32.4 & 248.9 & 533.4 \\
& $(17.8)$ & $(5.6)$ & $(31.4)$ & $(29.2)$ \\
$\begin{array}{l}\text { Hoop pine } \\
\text { (Lin et al. 2016) }\end{array}$ & 327.6 & 39.7 & 256.8 & 578.0 \\
Notes: $\mathrm{DF}$ = lateral impact vibration performance; $\mathrm{R}$ = drilling resistance value; $\mathrm{C}$ = crushing strength; $\mathrm{D}$ = air-dried density; parentheses ( ) indicate standard deviation.
\end{tabular}


Table 3. Transversal stress wave velocities $(V)$ of sound Japanese cedar trees ( $\mathrm{N}=$ number of sampled trees).

\begin{tabular}{|c|c|c|c|c|c|c|}
\hline \multirow[t]{2}{*}{ Groups } & \multirow[t]{2}{*}{$\mathrm{N}$} & \multirow{2}{*}{$\begin{array}{l}\text { Diagram of } 2 \mathrm{D} \\
(\mathrm{cm})\end{array}$} & \multirow{2}{*}{$\begin{array}{l}\mathrm{C} \\
\left(\mathrm{kgf} / \mathrm{cm}^{2}\right)\end{array}$} & \multicolumn{3}{|c|}{$\mathrm{V}(\mathrm{m} / \mathrm{sec})$} \\
\hline & & & & Vmin & Vmean & Vmax \\
\hline A & 15 & $\begin{array}{l}38.1 \\
(4.4)\end{array}$ & $\begin{array}{l}170.5 \\
(25.5)\end{array}$ & $\begin{array}{l}1463 \\
(139)\end{array}$ & $\begin{array}{l}1772 \\
(105)\end{array}$ & $\begin{array}{l}2080 \\
(99)\end{array}$ \\
\hline B & 14 & $\begin{array}{l}25.5 \\
(2.4)\end{array}$ & $\begin{array}{l}194.0 \\
(17.6)\end{array}$ & $\begin{array}{l}1220 \\
(88)\end{array}$ & $\begin{array}{l}1508 \\
(79)\end{array}$ & $\begin{array}{l}1796 \\
(95)\end{array}$ \\
\hline C & 15 & $\begin{array}{l}37.7 \\
(3.6)\end{array}$ & $\begin{array}{l}195.0 \\
(18.6)\end{array}$ & $\begin{array}{l}1441 \\
(81)\end{array}$ & $\begin{array}{l}1749 \\
(71)\end{array}$ & $\begin{array}{l}2056 \\
(88)\end{array}$ \\
\hline $\mathrm{D}$ & 15 & $\begin{array}{l}21.9 \\
(3.2)\end{array}$ & $\begin{array}{l}199.9 \\
(16.7)\end{array}$ & $\begin{array}{l}1159 \\
(81)\end{array}$ & $\begin{array}{l}1440 \\
(67)\end{array}$ & $\begin{array}{l}1721 \\
(88)\end{array}$ \\
\hline $\mathrm{E}$ & 15 & $\begin{array}{l}36.1 \\
(3.8)\end{array}$ & $\begin{array}{l}180.3 \\
(40.2)\end{array}$ & $\begin{array}{l}1488 \\
(96)\end{array}$ & $\begin{array}{l}1760 \\
(70)\end{array}$ & $\begin{array}{l}2031 \\
(70)\end{array}$ \\
\hline $\mathrm{F}$ & 15 & $\begin{array}{l}27.2 \\
(2.8)\end{array}$ & $\begin{array}{l}189.1 \\
(35.3)\end{array}$ & $\begin{array}{l}1354 \\
(66)\end{array}$ & $\begin{array}{l}1620 \\
(79)\end{array}$ & $\begin{array}{l}1887 \\
(130)\end{array}$ \\
\hline Average & & $\begin{array}{l}31.1 \\
(3.4)\end{array}$ & $\begin{array}{l}188.2 \\
(25.5)\end{array}$ & $\begin{array}{l}1354.2 \\
(91.8)\end{array}$ & $\begin{array}{l}1641.5 \\
(78.5)\end{array}$ & $\begin{array}{l}1928.5 \\
(95.0)\end{array}$ \\
\hline
\end{tabular}

Notes: $\mathrm{C}$ = crushing strength; Vmin = minimum stress wave velocity; Vmean = mean stress wave velocity; Vmax = maximum stress wave velocity; parentheses $($ ) indicate standard deviation. Groups A and B were planted in the Tower Area; Groups C and D were planted in Castle Area; Groups E and F were planted in the Ridge Area, Xitou Nature Education Area, Nantou, Taiwan.

Table 4. Transversal stress wave velocities $(V)$ of different damaged Japanese cedar trees (Group $G, N=24$ ).

\begin{tabular}{|c|c|c|c|c|}
\hline \multirow[t]{2}{*}{ No. } & \multirow{2}{*}{$\begin{array}{l}\text { Diagram of } 2 \mathrm{D} \\
(\mathrm{cm})\end{array}$} & \multicolumn{3}{|c|}{$\mathrm{V}(\mathrm{m} / \mathrm{sec})$} \\
\hline & & $\mathrm{Vmin}$ & Vmean & Vmax \\
\hline TR01_32 & 32.8 & 1414 & 1689 & 1965 \\
\hline TR01_96 & 28.7 & 1320 & 1560 & 1800 \\
\hline TR02_40 & 48.7 & 1333 & 1769 & 2206 \\
\hline TR02_115 & 44.3 & 1520 & 1755 & 1991 \\
\hline TR03 & 48.1 & 1424 & 1688 & 1952 \\
\hline TR04_40 & 55.1 & 915 & 1587 & 2259 \\
\hline TR04_120 & 46.5 & 1297 & 1690 & 2084 \\
\hline TR06 & 62.7 & 1544 & 1939 & 2334 \\
\hline TR07 & 48.7 & 1503 & 1804 & 2106 \\
\hline TR08_40 & 43.0 & 996 & 1554 & 2113 \\
\hline TR08_105 & 38.9 & 976 & 1490 & 2005 \\
\hline TR10 & 60.8 & 988 & 1614 & 2240 \\
\hline TR13 & 51.9 & 1588 & 1950 & 2313 \\
\hline TR14 & 45.5 & 1545 & 1951 & 2358 \\
\hline TR15 & 66.9 & 1751 & 2089 & 2428 \\
\hline TR16 & 76.4 & 818 & 1593 & 2368 \\
\hline TR17 & 83.1 & 757 & 1494 & 2232 \\
\hline TR19 & 48.7 & 730 & 1436 & 2143 \\
\hline TR20 & 32.5 & 1013 & 1341 & 1669 \\
\hline TR21 & 35.4 & 1010 & 1473 & 1936 \\
\hline TR22 & 28.3 & 674 & 1276 & 1879 \\
\hline TR23 & 41.4 & 1232 & 1643 & 2055 \\
\hline TS05 & 45.5 & 731 & 1115 & 1500 \\
\hline TS08 & 32.8 & 730 & 1140 & 1551 \\
\hline Average & $\begin{array}{l}47.8 \\
(13.9)\end{array}$ & $\begin{array}{l}1159 \\
(329)\end{array}$ & $\begin{array}{l}1610 \\
(247)\end{array}$ & $\begin{array}{l}2062 \\
(251)\end{array}$ \\
\hline
\end{tabular}

Notes: Vmin = minimum stress wave velocity; Vmean = mean stress wave velocity; Vmax = maximum stress wave velocity; parentheses ( ) indicate standard deviation. Group G was planted along both sides of the trail, Tower Area, Xitou Nature Education Area, Nantou, Taiwan.

The VT and corresponding V value maps were examined for the 89 undamaged and 24 decaydamaged Japanese cedar trees (Figure 1; Figure 2 ). None of the tomograms of the undamaged Japanese cedar trees displayed a distinct pattern of high and low $\mathrm{V}$ in the cross section of the stem (Figure 1). However, all tomograms of the decaydamaged Japanese cedar trees displayed a distinct pattern of high $\mathrm{V}$ (undamaged wood area) and low V (decay-damaged wood area) at the stem 
perimeter or center (Figure 2). The standard deviation values of minimum, maximum, and mean $\mathrm{V}$ in decay-damaged trees (Table 4) were clearly higher than those of undamaged trees (Table 3).

The relationships between transversal acoustic velocities (minimum, maximum, and mean) in 2D diameter values of undamaged Japanese cedar trees are shown in Figure 4. Acoustic velocity values generally increased with increasing diameter values. When expressed as linear regression relationships, the determined coefficient $\left(\mathrm{R}^{2}\right)$ were 0.66-0.71. Statistical analysis showed that the relationships between acoustic velocity and diameter values were significant at a 0.01 level. This result shows that these minimum acoustic velocity values (about $1,100-1,600 \mathrm{~m} / \mathrm{sec}$ ) tended to increase with increasing diameter (about 18.5-45.5 cm). The minimum $\mathrm{V}$ value can be considered as the threshold value of diagnosis by stress wave velocity tomography. Moreover, the $\mathrm{V}$ value was affected by diameter. Therefore, the $\mathrm{V}$ threshold value should be adjusted in the 2D diameter values.

The relationship between trunk diameter and the difference between maximum and minimum acoustic velocities (Vmax - Vmin) of the tomogram in undamaged and damaged trunk cross sections is presented in Figure 5. The average V value difference of the trunks in decay-damaged trees $(903 \pm 303 \mathrm{~m} / \mathrm{sec})$ was clearly higher than that of undamaged trees $(576 \pm 113 \mathrm{~m} / \mathrm{sec})$. This result shows that there is a higher risk of $\mathrm{V}$ value differences in decay-damaged trees, and lower differences occur in slightly decay-damaged trees. Moreover, differences between the maximum and minimum $\mathrm{V}$ value (Vmax and $\mathrm{Vmin}$ ) of the trunk in undamaged trees have to maintain a certain constant (about $300-800 \mathrm{~m} / \mathrm{sec}$ ). Therefore, this study suggests that the minimum transversal acoustic velocity with diameter, and the difference between Vmax and Vmin, could serve as the index of diagnosis or standard reference value.

\section{DISCUSSION}

The average $\mathrm{V}$ value, lateral impact vibration performance $(\mathrm{D} \bullet \mathrm{F})$, drilling resistance value $(\mathrm{R})$, green crushing strength $(\mathrm{C})$, and air-dried wood density (D) of a normal undamaged tree stem serve as the diagnosis index or standard reference value. Present here is a table of standard values for the future use of these devices or methods for testing Japanese cedar trees. The D • F, R, and C values of three tree species are compared and displayed in Table 2 for comparison (Lin et al. 2015; Lin et al. 2016). The average minimum acoustic

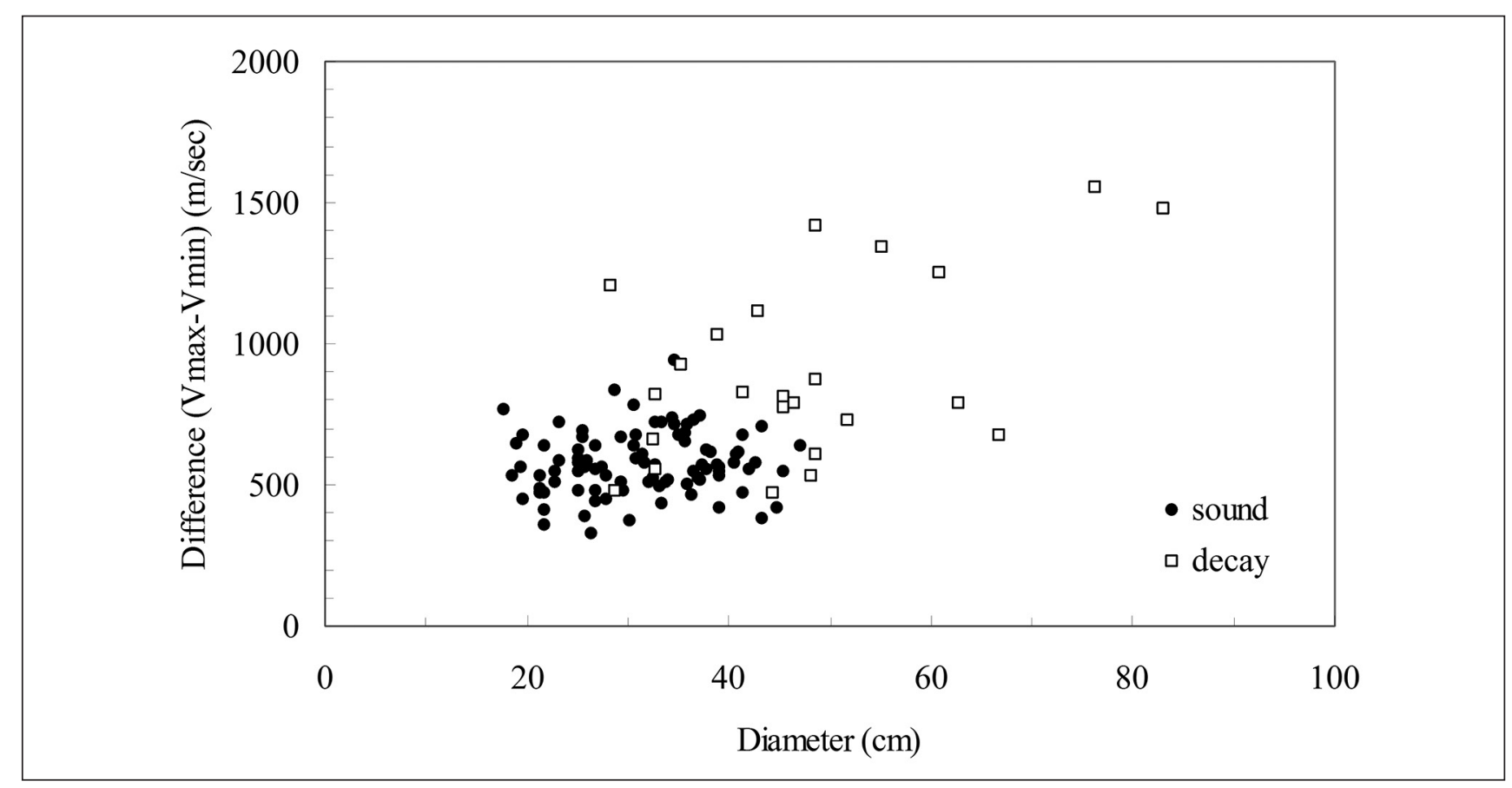

Figure 5. Relationships between the trunk diameter and the difference between maximum and minimum acoustic velocities (Vmax - Vmin) of the tomogram in undamaged $(\bullet)$ and damaged $(\square)$ trunk cross section. 
velocities of Japanese cedar, Norfolk island pine (Araucaria heteophylla), and hoop pine trees are $1,354,1,129-1,296$, and $1,154-1,164 \mathrm{~m} / \mathrm{sec}$, respectively. If detected values of nondestructive evaluation are lower than these reference values, the wood quality of the trunk brings up questions that could require further investigation.

In this study, lower transverse stress wave velocities (map grids) were observed inside of the decay-damaged trees. Severe wood decay defects have been reported when the stress wave velocity reduced to $70 \%$ of the characteristic values of sound wood (Bethge et al. 1996). In this study, the average $\mathrm{V}$ value in the undamaged trees were $1,642 \mathrm{~m} / \mathrm{sec}$ with the threshold at $1,148 \mathrm{~m} / \mathrm{sec}$ $(1,642 \times 0.7 \mathrm{~m} / \mathrm{sec})$. Moreover, the minimum $\mathrm{V}$ values of the tomogram in the undamaged trees were $1354 \mathrm{~m} / \mathrm{sec}$. Therefore, the minimum V values $(1,148-1,354 \mathrm{~m} / \mathrm{sec})$ can be considered as the threshold values for diagnosis by stress wave velocity tomogram. Furthermore, the range of demarcation between decay-damaged and undamaged wood occurred at an approximate transversal stress wave velocity of $1,148-1,354 \mathrm{~m} /$ sec. The reduction in $\mathrm{V}$ is indicative of serious damage, the location and extent of which can be seen in the map grids. The decay-damaged trees had lower average and individual stress wave velocities compared with the undamaged trees.

Some studies have reported that an acoustic tomogram cannot precisely evaluate the extent and location of decay or the type of defect (Gilbert and Smiley 2004; Wang et al. 2007; Wang et al. 2009; Li et al. 2011). For example, an acoustical tomogram underestimates the internal decay and overestimates that in the periphery of the trunk. Therefore, to make better assessments of internal conditions and decay of trees, other more effective methods (e.g., visual drawings of the increment core, drilling resistance, and use of a fractometer) should also be adopted in combination to enhance the accuracy of information.

In-depth tree assessments are warranted when a tree poses a high degree of risk to public safety and exhibits defects that cannot be fully evaluated by visual inspection (Pokorny 1992). However, micro-destructive methods can destroy the compartmentalization zone and break the existing barrier zone within the tree, allow- ing decay to spread into healthy wood. Therefore, when using decay detection devices, the number of drill holes or sensor sites for collecting the required critical field data should be kept to a minimum (Wang et al. 2007).

A larger thickness of the peripheral region and a higher ratio of peripheral wood toward the trunk base have significant implications for the tree structure and safety (sound and health). When Japanese cedar trees have trunk decay, deterioration, or hazardous defects, the residual wall thickness (shell) and wood quality have been found to be marginally sufficient. Most experts (Pokorny 1992; Matheny and Clark 1994; Harris et al. 2004; Hayes 2007) agree that a 30-35 ratio of percent sound wood in the remaining wall is the threshold beyond which some action should be taken.

The acoustic velocity values tended to increase with increasing diameter in this study (Figure 4). In this experiment, transversal $\mathrm{V}$ was detected by eight fixed probes along the circumference on the trunks. Moreover, the average crushing strength values of the larger diameter class were only slight lower than those of the smaller diameter class (Table 3 ) in the undamaged tree group. The properties (quality) and thickness (residual wall) of the peripheral wood in a tree is very important for the tree's structural safety and hazard evaluation. Generally, larger diameter trees with larger crowns need greater support, while the trunks of smaller diameter trees with smaller crowns need to withstand smaller forces. The deadweight and crown volume of the larger diameter class was larger than that of the smaller diameter class. The most important and dangerous load on trees is undoubtedly that created by wind, which can introduce bending stresses near the periphery of the stem (Mattheck and Breloer 1994). Previous research has indicated that the maximum V values of lean Norfolk island pine and lean hoop pine trees are greater than those of normal non-leaning trees (Lin et al. 2015; Lin et al. 2016). The leaning of a tree could result in reaction wood or larger gravity effects in the trunk of the tree. However, the V values of the cross section are influenced by the distribution of the cell structure, reaction wood, gravity, own 
weight, and other factors (i.e., combined action) in the tree. This might limit the applicability of VT. Further research is needed to clarify the intensities of individual factors in the future.

\section{CONCLUSIONS}

This study proposes a visual tree inspection form with seven categories of tree damage for tree hazard assessment. The average transversal acoustic velocities were $1,508-1,772 \mathrm{~m} / \mathrm{sec}$ for sound Japanese cedar trees. Moreover, the average lateral impact vibration performance, drilling resistance value, green crushing strength, and air-dried wood density were $384.6 \mathrm{~m} \mathrm{~Hz}, 18.5 \%, 186.2$ $\mathrm{kgf} / \mathrm{cm}^{2}$, and $500.4 \mathrm{~kg} / \mathrm{m}^{3}$, respectively. Different nondestructive evaluated parameters could serve as the index of the diagnosis value. A table of standard values for the future use of these nondestructive methods for testing Japanese cedar trees with and without decay damage is presented. The average minimum $\mathrm{V}$ values of the trunks in decay-damaged trees were clearly lower than those of sound trees. The V tomogram and corresponding stress wave velocity maps of decaydamaged and undamaged Japanese cedar tree can detect the general location and area of wood deterioration. The transversal acoustic velocity values increased with increasing diameter in sound trees, and the relationships could be represented by positive linear regression formulas. The minimum $\mathrm{V}$ and diameter values were $1,100-1,600 \mathrm{~m} / \mathrm{sec}$ and $18.5-45.5 \mathrm{~cm}$ in undamaged trees, respectively. The average difference between the maximum and minimum $\mathrm{V}$ value of the trunk in undamaged trees was $576 \pm 113$ (about 300-800) $\mathrm{m} / \mathrm{sec}$. These values can be considered as the threshold values of diagnosis by acoustic velocity tomography. The proposed method can be combined with other nondestructive techniques to better examine and confirm the situations of trees. 


\section{APPENDIX \\ Visual tree inspection form with seven categories of tree defects.}

\begin{tabular}{|c|c|}
\hline Defects & Items $\square$ detected $\square$ undetected \\
\hline 1. decayed wood & $\begin{array}{l}\square \text { decay or rotten } \square \text { fungi, fungal fruiting body } \square \text { cavity } \square \\
\text { hollows, hole } \square \text { inrolled cracks } \square \text { ever-expanding column of decay } \\
\square \text { bulge and swellings } \square \text { others (e.g., wound, wood discoloration, } \\
\text { canker) }\end{array}$ \\
\hline 2. cracks & $\begin{array}{l}\square \text { splitting of weak branch unions } \square \text { by pruning (e.g., flush-cut } \\
\text { pruning, topping) } \\
\square \text { wind (damage, sap flow, or bleeding) } \\
\square \text { vertical crack } \square \text { shear crack } \square \text { inrolled crack } \square \text { ribbed crack } \\
\square \text { horizontal crack } \\
\square \text { seam }\end{array}$ \\
\hline 3. root problems & $\begin{array}{l}\square \text { damage } \square \text { dead } \square \text { lost } \square \text { crack } \square \text { decay } \square \text { lean } \square \text { fungal fruiting } \\
\text { body } \square \text { root breakage } \square \text { stem girdling root } \square \text { others (e.g., disease, } \\
\text { disorder, ants, etc.) } \\
\square \text { critical root radius was disturbed, damaged or restricted leading } \\
\quad \text { to reduced anchoring ability of roots } \\
\square \text { crown decline } \\
\square \text { lean } \square \text { soil mounding } \square \text { soil cracking } \square \text { root lifting }\end{array}$ \\
\hline $\begin{array}{l}\text { 4. weak branch } \\
\text { unions }\end{array}$ & $\begin{array}{l}\square \text { co-dominant stems or branches } \square \text { epicormic branch } \square \text { included } \\
\text { bark } \square \text { others (e.g., topping, injured, pruned, crack, or declining } \\
\text { branches) }\end{array}$ \\
\hline 5. cankers & $\begin{array}{l}\square \text { canker } \square \text { fungi } \square \text { insect (e.g., termite) } \square \text { microorganism } \square \\
\text { mechanical damage } \square \text { other (e.g., lightning) }\end{array}$ \\
\hline $\begin{array}{l}\text { 6. poor tree } \\
\text { architecture } \\
\text { (trunk and } \\
\text { branch) }\end{array}$ & $\begin{array}{l}\square \text { leaning } \square \text { tension or buckle symptom } \square \text { epicormic branch, harp } \\
\text { tree } \square \text { unbalance crown } \square \text { others (e.g., bends, twists, and crooks) }\end{array}$ \\
\hline $\begin{array}{l}\text { 7. dead trees, } \\
\text { tops, or branches }\end{array}$ & $\square$ dead trees $\square$ dead tops $\square$ dead branches \\
\hline
\end{tabular}


Acknowledgments. The authors wish to thank the Experimental Forest, National Taiwan University, and Taiwan Forestry Research Institute for financial support.

\section{LITERATURE CITED}

Bethge, K., C. Mattheck, and E. Hunger. 1996. Equipment for detection and evaluation of incipient decay in trees. Journal of Arboriculture 20:13-37.

Bucur, V. 2005. Ultrasonic techniques for nondestructive testing of standing trees. Ultrasonics 43:237-239.

Deflorio, G., S. Fink, and F.W.M. Schwarze. 2008. Detection of incipient decay in tree stems with sonic tomography after wounding and fungal inoculation. Wood Science and Technology 42:117-132.

Gilbert, E., and E.T. Smiley. 2004. PiCUS sonic tomography for the quantification of decay in white oak (Quercus alba) and hickory (Carya spp.). Journal of Arboriculture 30:277-281.

Gruber, F. 2008. Untenable failure criteria for trees: 1 . The residual shell wall thickness rule. Arboricultural Journal 31:5-18.

Harris, R.W., J.R. Clark, and N.P. Matheny. 2004. Arboriculture: Integrated management of landscape trees, shrubs, and vines. Pearson Education, Upper Saddle River, New Jersey, U.S. pp. 405-433.

Hayes, E. 2007. Evaluating tree defects, a field guide. Safetrees LLC, Rochester, Minnesota, U.S. 30 pp.

Larsson, B., B. Bengtsson, and M. Gustafsson. 2004. Nondestructive detection of decay in living trees. Tree Physiology 24:853-858.

Li, H.F., H.T. Yeh, Y.N. Wang, and M.J. Tsai. 2011. Termite Diversity and Damage Pattern in Tropical Botanical Garden of Taiwan. Journal of the Experimental Forest of National Taiwan University 25(2):139-147.

Lin, C.J., C.H. Chung, M.L. Wu, and C.L. Cho. 2013. Detection of Phellinus noxius decay in Sterculia foetida tree. Journal of Tropical Forest Science 25(4):487-496.

Lin, C.J., C.M. Chiu, and S.Y. Wang. 2000. Application of ultrasound in detecting wood decay in squirrel-damaged standing trees of Luanta China fir. Taiwan Journal of Forest Science 15:267-279.

Lin, C.J., S.Y. Wang, and C.M. Chiu. 2007. Crushing strength sampling with minimal damage to Taiwania (Taiwania cryptomerioides) using a fractometer. Wood and Fiber Science 39:39-47.

Lin, C.J., T.T. Chang, M.Y. Juan, and T.T. Lin. 2011a. Detecting deterioration in royal palm (Roystonea regia) using ultrasonic tomographic and resistance microdrilling techniques. Journal of Tropical Forest Science 23:260-270.

Lin, C.J., T.T. Chang, M.Y. Juan, T.T. Lin, CL Tseng, Y.N. Wang, and M.J. Tsai. 2011b. Stress wave tomography for the quantification of artificial hole detection in camphor trees (Cinnamomum camphora). Taiwan Journal of Forest Science 26(1):17-32.

Lin, C.J., Y.C. Kao, T..T Lin, M.J. Tsai, S.Y. Wang, L.D. Lin, Y.N. Wang, and M.H. Chan. 2008. Application of an ultrasonic tomographic technique for detecting defects in standing trees. International Biodeterioration and Biodegradation 43:237-239.

Lin, C.J., Y.H. Huang, G.S. Huang, and M.L. Wu. 2015. Detection and evaluation of termite damage in Norfolk island pine (Araucaria heteaophylla) trees by nondestructive techniques. Journal Experiment Forest National Taiwan University 29(2):79-90.
Lin, C.J., Y.H. Huang, G.S. Huang, M.L. Wu, and T.H. Yang. 2016. Detection of termite damage in hoop pine (Araucaria cunninghamii) trees by nondestructive techniques. Journal of Tropical Forest Science 28(1):79-87.

Matheny, N.P., and J.R. Clark. 1994. A photographic guide to the evaluation of hazard trees in urban areas. International Society of Arboriculture, Champaign, Illinois, U.S. 85 pp.

Mattheck, C., and H. Breloer. 1994. Field guide for visual tree assessment (VTA). Journal of Arboricultural 18:1-23.

Pellerin, R.F., and R.J. Ross. 2002. Nondestructive Evaluation of Wood. Forest Products Society, Madison.

Pokorny, J.D. 1992. Urban Tree Risk Management: A Community Guide to Program Design and Implementation. USDA Forest Service Northeastern Area State and Private Forestry, St. Paul.

Rinn, F. 1999. Device for investigation materials. U.S.-Patent US6813948; International Patent PCT/DE00/01467 (1999.05.11). [Basic patent describing sonic tomography].

Rinn, F. 2011. Basic aspects of mechanical stability of tree cross sections. Arborist News 20(1):52-54.

Wang, X., and R.B. Allison. 2008. Decay detection in red oak trees using a combination of visual inspection, acoustic testing, and resistance microdrilling. Arboriculture \& Urban Forestry 34:1-4.

Wang, X., J. Wiedenbeck, and S. Liang. 2009. Acoustic tomography for decay detection in black cherry trees. Wood and Fiber Science 41:127-137.

Wang, X., J. Wiedenbeck, R.J. Ross, J.W. Forsman, J.R. Erickson, C. Pilon, B. Brashaw. 2005. Nondestructive Evaluation of Incipient Decay in Hardwood Logs. General Technical Report FPLGTR-162. U.S. Department of Agriculture, Madison.

Wang, X., R.B. Allison, L. Wang, and R.J. Ross. 2007. Acoustic Tomography for Decay Detection in Red Oak Trees. Research Paper FPL-RP-642. U.S. Department of Agriculture, Madison.

\section{Cheng-Jung Lin (corresponding author) \\ Associate Researcher \\ Forest Utilization Division \\ Taiwan Forestry Research Institute \\ 53 Nanhai Rd. \\ Taipei 10066, Taiwan \\ zzlin@tfri.gov.tw}

Chia-Ju Lee

Research Assistant

The Experimental Forest

National Taiwan University

Taiwan

Ming-Jer Tsai

Professor

School of Forestry and Resource Conservation

College of Bio-Resources and Agriculture

National Taiwan University

Taiwan 
Résumé. L'objet de cette étude était d'étudier les valeurs standard de cèdres du Japon (Cryptomeria japonica) en santé et sans dommages, en utilisant différentes techniques non destructrices. Cette étude a également évalué la vélocité de l'onde de contrainte (V) et du tomogramme (VT), et solutionné les cartes correspondantes $\mathrm{V}$ du cèdre du Japon avec et sans dommages causés par la carie quant à l'évaluation des risques liés aux arbres. Un formulaire pour l'inspection visuelle des arbres, comportant sept catégories de dommages aux arbres, est proposé pour l'évaluation des dangers liés aux arbres. Différents paramètres d'évaluation non destructifs peuvent servir d'indice pour le diagnostic des valeurs standard (avec ou sans carie). Les VT et les cartes correspondantes de la vélocité de l'onde de contrainte de cèdres du Japon endommagés par la carie ou par d'autres dommages peuvent détecter l'emplacement relatif et l'aire de dégradation du bois. Les valeurs acoustiques transversales de vélocité augmentèrent avec l'accroissement du diamètre chez les arbres non endommagés, et la différence entre la valeur $\mathrm{V}$ maximale et minimale des troncs chez les arbres non endommagés se situaient à l'intérieur des constantes. L'approche proposée peut être combinée avec d'autres techniques non destructrices afin de mieux évaluer et confirmer la condition des arbres.

Zusammenfassung. Die Absicht dieser Studie lag in der Untersuchung von Standartwerten für lebende, unverletzte Japanische Zedern (Cryptomeria japonica) mit verschiedenen, verletzungsfreien Techniken. Diese Studie zeigt auch die Stresswellengeschwindigkeit (V) und das Stresswellentomogramm (VT) und erklärt korrespodierende V-Aufzeichnungen von Japanische Zedern mit und ohne Verletzungen. Ein visuelles Baumuntersuchungsformular mit sieben Kategorien von Baumschäden wird für die Baumuntersuchung vorgestellt. Verschiedene verletzungsfreie Bewertungsparameter können als ein Index für die Diagnose von Standartwerten (mit oder ohne Fäulnis) verwendet werden. Die VT und dienkorrespondierenden Aufzeichnungen der Stresswellengeschwindigkeit von geschädigten und fäulnisbehafteten Japanischen Zedern können den Ort und die Gegend der Holzverfärbung aufzeigen. Die Werte der transversalen akustischen Geschwindigkêit stiegen mit zunehmendem Durchmesser bei ungeschäigten Bäumen innerhalb einer Spanne von Konstanten. Der vorgestellte Ansatz kann mit anderen verletzungsfreien Techniken kombiniert werden, um zu besseren Untersuchungsergebnissen zu gelangen und den Status des Baumes zu bestätigen.

Resumen. El propósito de este estudio fue investigar los valores estándar de nivel de vida de árboles de cedro japonés (Cryptomeria japonica), a través de diferentes técnicas no destructivas. Este estudio también detecta la velocidad de onda del estrés (V) y la tomografía (VT) y resuelve mapas V correspondiente de cedros japoneses con y sin daños de decaimiento para la evaluación de riesgos del árbol. Una forma de inspección visual del árbol, con siete categorías de daños a los árboles es propuesta para la evaluación del daño del árbol. Diferentes parámetros de evaluación no destructivos pueden servir como un índice para el diagnóstico de los valores estándar (con o sin descomposición). Los mapas VT y de velocidad de estrés y la correspondiente tensión de cedros japoneses dañados pueden detectar la ubicación general y el área de deterioro de la madera. Los valores de velocidad acústicas transversales aumentaron con el aumento de diámetro en los árboles no dañados, y la diferencia entre el valor $\mathrm{V}$ máximo y mínimo de los troncos de los árboles no dañados cayeron dentro de un rango de constantes. El enfoque propuesto se puede combinar con otras técnicas no destructivas para examinar mejor y confirmar la situación de los árboles. 